\title{
GEOPOLITICAL DIMENSION OF NEPALAND ITS IMPACT IN SOUTH ASIA
}

\author{
Umesh K. Bhattarai
}

\begin{abstract}
International security and its relevancy to nation's stability are heavily influenced by the geo-political situation of a country. By geo-politics, it is a relationship among politics, geography, demography, and economics-especially in respect to foreign policy adopted by a nation within the region. It dictates the overall governmental policies. In other words, the power relationship is dictated by the geographic location of the country. Geo-politics is the study of the political and strategic relevance of geography in a pursuit to national and international power (Khanal, 2011). So, the location and the physical environment are important factors to decide international power structure of a nation in the global as well as in regional context. Geo-strategy is a branch of geo-politics that deals with strategy. It characterizes a certain geographic area that affects the analysis of a region (Dahal, 2009). In order to understand the importance of geo-strategy of Nepal, we need to understand geographical context of the Indian subcontinent as a whole. It is a self-contained region that includes India, Pakistan, Bangladesh, Nepal and Bhutan. We may call the subcontinent "self-contained" because it is a region that is isolated on all sides by difficult terrain or by ocean. In geopolitical terms it is-an island (Friedman, 2008)
\end{abstract}

\section{'Nationalism' within the State of Nepal}

The rebellion is not a new subject in the Nepali history since the integration of present Nepal by king Prithvi Narayan Shah. The conspiracy and struggle for power are common. During royal regime- the palace was the center of gravity for power politics and the elites used to revolve in and around the palace. These elites misguided the royalty and exploited the poor Nepali.

The deep-rooted differences within the Nepali society surfaced at the spontaneous process of development have later transformed into the conflict. The scarcity of the resources, illiteracy, poverty and unequal distribution of opportunity have created a catastrophic effect to burn conflict. At the state leveldiscrimination based on tribe, language and the religion was distinct in all sectors of social life (Subedi, 2010: 72). 
The Maoist rebellion, in a decade time-geared-up so fast that almost 242 year's old royal regime trembled. The very reason for this down fall was nothing other than the inability to meet the popular aspiration of the people, lack of willingness of the old structure to reform the outdated feudalistic mode of society and suffocation of normal people from elite ruling system. In addition, the inequality in access to resources and opportunities, inadequate service delivery, injustice to the identities and political ideological beliefs, ineffective governance, inept transparency and accountability, intolerant bureaucracy and technocracy as well as insipid diplomacy can be blamed for instability in Nepal.

It is believed that King Prithvi Narayan Shah could integrate Nepal geographically to one state but he failed to unite the country on the basis of ethnicity, religion, language, class, and culture. Nepal could become a state but it could not become a nation even from the days of its integration. Hence, emotional attachment of its citizen in the form of nation-state remained fragmented.

Crisis is an event that measures human endurance to tackle it. The endurance differs from person to person, society to society and nation to nation based on its survivability and past experiences. History of any nation depicts its ability to cope up such crisis and also to measuring the 'nationalism' among its people. The feeling of 'nationalism' can be felt and gauged at the time of national crisis. The people generally tend to unite when they feel insecure from outside. In normal situation, the feeling of 'nationalism' remains dormant.

Nepalis are relatively passive, shy, humble and poor but self-esteemed, independent and hard-working. The crisis of last Mega-Earthquake of April 25, 2015 was the acid test for all Nepali leaders to reconstruct the damaged infrastructures and support to the victims- but they failed to garner consensus and mobilize the resources. Due to severe politicization, they not only loosed the trust of Nepali people- but also they are discredited in the international community.

\section{Regional Power Balance}

The Indian subcontinent, on its northern side of the mountain wall-there is two countries, Nepal and Bhutan, which pose no threat to India. On the other side lies China which can be considered threat to India, and in simplistic word may be a potential rival. Their entire frontier runs through the highest elevations of the Himalayas and both are walled off from each other. The only major direct clash between Indian and Chinese forces, which occurred in 1962, was an inconclusive battle over border territories high in the mountains-both in the northeast Indian state of Arunachal Pradesh and the Kashmir region. The relation over the 
territorial dispute is still active as Chinese authority opposed the recent visit of PM NarendraModi to Arunachal Pradesh capital Tawangclaiming that it belongs to their territory.

A potential geopolitical shift would be there if the situation in Tibet is changed. China's main population centers are surrounded by buffer states-Manchuria, Inner Mongolia, Xinjiang and Tibet. As long as all these states are in Chinese hands, the core of China is invulnerable to land attack. If, Tibet becomes independent, and if it allies with India, so as it permits India to base substantial forces in its territory and to build major supply infrastructure there, then-and only then-India could be a threat to China. This is why India for a long time advocated for Dalai Lama and Tibetan independence movements. If a pro-Indian, independent government be installed in Tibet-the threat to China would be significant.

Similarly, China may develop equivalent threats to India-particularly in the form of Maoist communist insurgencies. Indian as well as Nepali Maoists has been suspected on getting support by Beijing though China has lost interest in aggressive Maoism. But it does have an interest in maintaining influence in Nepal. This may be China's counter to India's Tibet policy. Using Nepal as a base from which to invade India would be similarly difficult and pointless for Beijing. At the moment, there is no Indo-Chinese geopolitical hostility. However, these would be points of friction if such hostility were to occur in the distant future.

The present development in US-India relations to provide logistics base to the US, lobbying India for membership in NSG and support to acquire MTCR will definitely annoy China and Pakistan. Perhaps, the USA might be encouraged to counter China's assertive military posture in South China Sea and Indian Ocean through India that is why it is supporting India for NSG although it has not signed Non Proliferation Treaty as well.

The justification for membership in NSG for clean energy may be acceptable but acquiring MTCR is different. Logistics base to the US is also matter of debate to the neighbors. A cordial relation between regional power and super power is much appreciable but collaboration against neighboring global power will possibly encourage hostilities. In retaliation, if China adopts assertive position through military presence in any of the neighboring South Asian country to Indiait will be devastating to security and stability for the entire region. So, India as well as China must restraint and careful when they opt for any decision that may destabilize the region. 
Equally, Nepal should also realize its pivotal position in the Himalayas between the Central and South Asian Region. Its geographical position forms a critical geo-strategic setting for the security of India especially to its Gangatic belt; and to the North-existence of the sensitive Tibet-Autonomous Region of China; which has made Nepal's position more strategic (Khanal, 2011). In view of this, Nepal needs to formulate its foreign policy satisfying both the neighbors' interest carefully. At the same time, promoting own interest from growing economies of both the countries will be a wise part to use geo-strategic setting for Nepal.

\section{Nepal-Compounded by Three Nuclear Powers}

The global focus on South Asia and the Indian Ocean has increased over the years due to India and the emerging world power China. In spite of this, another world power has its stakes in the region that is USA. It is the dominant world power for the past century which is an active partner waging an unfinished war on terror in the Afghanistan- Pakistan region and now in Middle-East. Despite of its continued dominance in the Pacific-it is continuously exerting pressure on South Asia equally so as to balance China in this region.

In fact, being buffer between two nuclear powers directly under Indo-China domain and Pakistan in near distance-Nepal is getting priority on foreign aid from regional as well as global powers. This is basically to influence in formulating public policies and setting priorities. The weaknesses of the executive authority, the poverty of homegrown ideas and heavy reliance on donors for financing development has made government prone to donors. It has crippled both the democratic authority of the government and the bureaucracy, thereby weakening the ability of the state to work in the public interest. The Nepali state has failed to assert itself over the donors' interests. It is a sensitive issue on the part of Nepali side to remain in balance for not to compromise on its own national interest at any cost.

The balance of power is very important to maintain stability. The deterrence effect itself controls one to another. The consequences of war are devastating for the nations-so the power equilibrium itself is the indicator of the tension of war in the region. In order to balance the power-the rival invests major portion of its public budget in the defense. Guided by this philosophy, South Asia is geopolitically and geo-strategically important due to its unique location. Starting from Russia to Down China, India and Pakistan are four nuclear powers. One shares border with the other nuclear actor. Security is very important in this 
nuclear armed belt. Any event can lead India-Pakistan to the brink of nuclear war. If the balance of power is maintained in the region it may create an environment of mutual deterrence. Dynamics of balance of power are very important in South Asia. Whenever the balance of power of the region got disturbed there happens a war. China as a biggest stake holder in Asia plays a role in maintenance of balance of power in the region (Naseer, Amin, 2011: 17).

India and the US are the co-partners dealing with international terrorism and stabilizing Afghanistan and Pakistan, though their approach is significantly different. India pursue more aggressive US role in dealing with terrorism in Pakistan, on contrary Pakistan is warning against such aggressive attempts and views it may lead to nuclear confrontation. Pakistan and India have deep-rooted bilateral problem over Kashmir issue. While working closely with the US, India seeks 'strategic autonomy' in achieving its foreign policy goals-often it puts New Delhi at odds with Washington as what happened to support US position over Syrian issue in the Security Council recently.

China's influence in South Asia is increasing day by day. In context to Bangladesh, it got independence due to Indian support from Pakistan, though it signed an agreement with China for the atomic power besides of having a huge reserve of natural gas and coal. Bangladesh also preferred to offer China for the construction of the port infrastructure in Sumadia Island and Chittagong.

Pakistan, from the days of its independence in 1947, has fought three wars with India over the territorial disputes of Kashmir, shares cordial relation with China who is the co-partner for making Pakistan a nuclear power state. China is also the largest foreign investor for copper exploration in Afghanistan from May 2008 besides of US huge presence there. China's involvement in large projects like 400 Mega watt coal power house along with construction project of railway of Kazakhstan-Afghanistan and Pakistan link has increased China's influence in Afghanistan.

\section{Nepali Political Transition Vs South Asian Stability}

As India is pivot in South Asia - any disturbance in this region affects it. So as Maoist insurgency in Nepal have a direct link to Indian security chain in the past and in the present as well. Maoist insurgency is not new for India. It has started 43 years ago from the small township of Naxalbari in West Bengal and now has spread in a large area besides of being India an emerging power in the world. The economic boom of India has not been inclusive for a major segment of the 
poor and lower caste ethnic groups who have no reach to the outcome of such an economic development in the country.

Altogether 6 thousand people have died from the Maoist insurgency in India. The decade long Maoist rebellion in Nepal has witnessed 17 thousand people dead which may be a lesser amount of human loss in 43 years in the history of Indian Maoist insurgency. But, many have anticipated that the actual conflict in India is likely to gear up now onwards. The last government of the Congress and present government ofBhartiyaJanata Party (BJP) both are in favor of conducting decisive campaign against the Maoist. Sonia Gandhi, in an open party letter wrote that while they must address acts of terror decisively and forcefully they need to address the root causes. The Maoist growing strength highlights the need for development efforts to reach the "Maoist backward districts". The rise of the Maoist in India reflects the need for development initiatives to reach the grassroots.

The Nepali Maoist has been charging India for the entire deadlock in Nepal's peace process. And India too has to bear responsibility for political impasse as what Professor SD Muni has accepted in the interview. He further reiterated as what the Maoist say that India is entirely responsible is not correct. All five components of Nepali Politics (Maoist, NC, UML, Madhesi alliance and the international community) are responsible for the mess in Nepal. India has gone away from consensus. That is the main fault. In some respect, India has also gone away from the democratic principle that the largest party should lead the government in Nepal (Muni, 2010).

The then Indian Ambassador Jayant Prasad in South Asian Forum for Policy Studies on February 15, 2012 revealed that there are three political powers in Nepal; the statement contradicts SD Muni's apprehension of five components of Nepali politics. SD Muni missed out monarchical power which is dormant presently but persists in the society. The fact cannot be ignored from the conflict transformationwhich suggests for win/win perspective. The economic uplift through systematic development of the nation, application of proper power sharing mechanism, establishment of ownership are few tools to balance the grievances in the society. $\mathrm{T}$

\section{Nepali Geopolitical Dimension Vs Regional Stability}

Nepal is independent from the date of its evolution. During the British rule in India- its feudal rulers managed to stay relatively independent by offering 
diplomatic and military support to the British. Britain wanted Tibet as a buffer with China - not Nepal that time. Due to various reasons- British could not conquer Nepal; though it trapped it by supporting autocratic rulers to prolong their regime. The Sughauli Treaty of 1816 has trapped Nepal to become de-facto colonial state of Britain though most historians do not accept this fact.

The Nehru doctrine was the continuation of the British philosophy. The Indian regime supported the democratic alliance under the Nepali Congress to abolish Rana autocracy at one side and in a chronicling deal forced Rana ruler to sign the Peace and Friendship Treaty in 1950. Most Nepali think they are deprived of their rights due to this unequal treaty - it is said unequal because there cannot be an equality which is not only landlocked - it is India locked by three sides. Besides to this, there is no comparison on power balance. The privilege and facilities provided by International Conventions are also deprived at times due to this treaty.

Most Nepali perceives that India's concern with Nepali politics is focused towards security from the north and economic advantage that Nepal enriched with natural resources. The huge Nepali market is another important source of income for Indian products. To secure all these- India is continuously influencing the weak and fragile politics. The motives behind such intension are proved through several interventions usually aimed to empowering a proxy political force to topple Rana regime in 1950, setting back Late King Birendra's peace zone proposal in 1990 and covert support to Maoist as well as overt support to royal regime to fight each other from 1996 to 2004. India declined its support to royal regime to fight against the insurgency in 2004 due to Ex-King Gyanendra's autocratic move in Nepal.

On the other side, China-though it does not fall in South Asia- carries interest in this region. President Xi Jingping's visit to India in last September 2014 was not uncontroversial. He reached to Ahmadabad in Gujarat after the visit to Sri-Lanka. As most speculates- China is eager to open the old sea bound Silk Road from South China Sea via Strait of Malacca - Strait of Hormuz to Middle East, west Asia as well as Africa.Similarly it is advocating for 'one belt- one road' and has plan to develop old land bound Silk Road through central Asia connecting Europe.China is also aggressively laying the railway lines connecting from Beijing to Nepal border to get inside the huge Indian market in the south. Tibet is the nerve point where China is blamed for 'expansionist' by the US and west whereas Sikkim annexation by India was not significantly criticized as well. 
If we see the past, both India and China have played dirty games to annex the weak neighbors through a chronicle self-made situation in the region. China's interest in Nepal is heavily influenced by Tibetan issue. China could benefit if it can dilute western influence in Nepal.

Indo-Nepal relations, though it is cordial needs some flash back to further shine up in the present days scenario. Nepali speaking Bhutanese residing in Southern Bhutan were displaced to India and further to Nepal. The first point of entry for these displaced people was India as Nepal- Bhutan has no common border. They were pushed to Nepal rather to their own country as India had privileged relations with Bhutan (foreign and defense policy was looked after by India that time). On contrary, Nepal is more cautious about its independence, freedom and sovereignty. That is why, from Indian perspective-Bhutan was closer than Nepal.

Furthermore, the main cause of antipathy towards Indian hegemony starts from 1989 when India imposed economic blockade to Nepal to punish royal regime but the ultimate sufferer were the people. The blockade was for the cause Nepal's acquisition of Chinese anti-aircraft guns showing the clause of Indo-Nepal Treaty of 1950 which speaks about consent to be taken while acquiring weapons from third country. If so, has India taken Nepal's consent when it equipped its army as well? The recent five months 'undeclared' economic blockade by Indian Establishment though it does not agree was due to Nepal's declaration of it constitution from the elected constitutional assembly.

The case of unique 'open border' between huge India and small Nepal has different connotations. The trade deficit of Nepal is huge and cumulating day by day with India. Besides of realizing the need to regulate the border by both the countries, no initiation has taken from either side in this regard. In the changed scenario of South Asia, India may not be willing to lose its influence in Nepal as it has with Sri Lanka. So, Nepal- India relations should be reviewed and modified with the changed dynamics in this region otherwise the existence of small country like Nepal will be jeopardized.

China is more or less mute on the issues concerned to bilateral relations of the neighbors. The situation has changed after the five month 'undeclared' blockade by India. The popular demand for trade diversification has forced KP Sharma Oli's Government to incline towards China. It insists as the foreign policy should base on the 'principle of panchasil' and has advocated accordingly. Nepal is suspicious with Indian move to annex Sikkim in 1975. Due to this, it was slightly 
inclined towards China. In the cold war era, Nepal could promote its national interest through 'non-aligned policy' having equi-distance to both the countries. The bilateral relation with India gradually declined after late King Birendra's peace zone proposal to Nepal. The interpretation of the clauses of Indo-Nepal Treaty-1950 remained the 'hot-cake' for both the countries. The climax of their hyper relations ended in 1990 when King Birendra agreed to remain constitutional head.

The multi- party democracy could not move as per the people's desire. In nutshell, the guardians of it could not empower the people rather they became liabilities to the nation. The pace of development and stability could not gear-up. The slogan of 'good governance' remained in the paper only. The rampant corruption spoiled the entire ethics of the society. In such a situation, the Communist Party of Nepal (Maoist) raised the weapon against the system in 1996. Nepal witnessed a decade long insurgency which ended in 2006 via 12 Point Agreement mediated by Indian Establishment.

Despite of Nepal experiencing more than 250 years of statehood, still trying to make it 'nation-state' as per modern European philosophy. Having more than six constitutions in six decade of time-frame from 'first revolution' in 1950 against the Rana rulers- Nepal is unable to experience 'true democracy' - through fully people's empowered system. What is the main hurdle? The question goes to all national as well as international powers. Why Nepal had the catastrophic effect of conflict in more intensity compared to other places? Is Nepal's geopolitics a sole reason of it? Or it is due to the vested interest of the neighbors? We need to answer these questions frankly otherwise the blaze of fire will not only destroy Nepal but also the entire region will be destabilized.

Apparently, Chinese interest in Nepal looks like to dilute western as well as Indian influence to weaken China raising the issues of 'free Tibet'- so it has covertly increased the surveillance activities in Indo-Nepal border. At the same time- to monitor the activities of the westerns, it has increased Chinese presence in the tourist hub areas through restaurants/cafes and even in the travel/trade business in Nepal. Similarly, Pakistan's anti-India elements are using open IndoNepal border to smuggle the fake currency to weaken the Indian monetary market, so as Nepali fake currency is smuggled to Nepal. Contra-band drugs and new routes for gold smuggling from China to India through this open trans-national border have undermined the security apparatus of both the countries. The fragile politics of Nepal and like- minded attitude of neighbors has encouraged the anti- 
72 Journal of International Affairs Vol. 1, No. 1, 2016

social elements to flourish in Nepal. In consideration to geopolitical situation, Nepal must be cautious to such elements and promote 'good governance' at one side - the neighboring India and China should also care for Nepal to make it more stable at other side. Hence, 'only stable Nepal' can help to become a bridge between two global powers 'India and China' to make 'South Asia' economically vibrant region.

\section{End Notes}

Chaturvedy, Rajeev Ranjan. Malone, David M. ( 2012). A Yam between Two Boulders.In Einsiedel, Sebastian Von. Malone. David M. \&PradhanSuman. (Ed). Nepal in Transition: From People's War to Fragile Peace. New Delhi: Cambridge University Press.

Dahal, Ram Kumar."Emerging role of Nepalese diplomacy in regional and global politics."The Weekly Mirror.2009.

Friedman, George. (2008).The Geo-politics of India: A Shifting, Self-Contained World. The Himalayan Times

Khanal, Rabindra.(2011). Geo-Politics and Socio-Political Development in Nepal. The Shivapuri.P-2.

Muni, SD. (2012).Bringing the Maoist Down from the Hills: India's Role. In Einsiedel, Sebastian Von., Malone,David M.,\&Pradhan, Suman. (Ed.). Nepal in Transition: From People's War to Fragile Peace. New Delhi : Cambridge University Press.

---. (2010, November 28). Interview.Kantipur Daily, the Kathmandu Post.p$7 \& 8$.

Naseer, Rizwan.,\& Amin, Musarat. (2011, January 1). Dynamics of Balance of Power in South Asia: Implications for Regional Peace.Berkeley Journal of Social Sciences Vol. 1.p-20-21.

Rose, Leo E. (1971). Nepal Strategy for Survival. New Delhi: Oxford University Press.

Raapana, Niki. Friedrich, Nordika. (2005). What is the Helelian Dialectics. http://www.crossroad.to/articles2/05/dialectic.htm (Accessed on March 13, 2013).

Subedi, Hemraj. (2010). Dwanda, Santi Ra Bikash Adhyan Bibhag, Rananiti Ra Chunauti. A Special Bulletin of Tribhuwan University. 